\title{
A suksükölő igeragozás
}

\author{
SINKOVICS BALÁZS
}

\section{Bevezetö}

A mai magyar beszélőközösségben az egyik legmegbélyegzettebb nemstandard változat a suksükölésnek nevezett jelenség, vagyis ha a beszélök a $t$ végü igék esetében a kijelentő mód határozott ragozásában a felszólító móddal egyező alakokat használnak. Tanulmányomban e nyelvi jelenség keletkezésének és a megbélyegzés kialakulásának történetét mutatom be. Elöször ismertetem a nyelvi változókat, ezután a történeti, illetőleg nyelvjárástörténeti adatokat a 19. század végéig, majd a 20. századi nyelvjárási és szociolingvisztikai kutatások eredményeit és tanulságait, végül a nyelvi megítélés és a megbélyegzés alakulását napjainkig.

A standard magyarban a $t$ végü igék egyes határozott ragozású kijelentő módú alakjai különböznek a felszólító módúaktól, a nemstandard magyarban azonban a megfelelő alakok azonosak. Vagyis magas hangrendü igék esetében többes szám első személyben, mély hangrendủ igék esetében pedig egyes szám harmadik személyben és a többes számú paradigma minden tagjában a standard felszólító módú alakokkal azonos formák jelennek meg a kijelentő mód jelen idő határozott ragozásában (megadhassa, megadhassuk, megadhassátok, megadhassák a standard megadhatjuk, megadhatják stb. helyett). Ez utóbbi az egyik legerősebben stigmatizált nemstandard változat, ezért stigmatizált magyar felszólító módnak nevezhetjük (vö. VÁRADI-KONTRA 1994, KONTRA 2003a: 77). A $t$ végü igéken belül külön kell választani az szt végü igéket, mivel az adatok alapján aki suksüköl, az szukszüköl is, vannak azonban olyan beszélök, akik csak szukszükölnek, de nem suksükölnek (CSERNICSKÓ 2002, KONTRA 2003b: 131-145, VARGHA 2007: 280-282).

\section{Történeti adatok}

A jelenség kialakulásával, elterjedésével részletesebben mindezidáig csak KovALOVSZKY MiKLÓs foglalkozott (1953a, 1956, 1959), véleményem szerint meglehetősen elfogult nyelvmüvelő szemszögből. A kérdést a magyar igeragozás 
története kapcsán tárgyalta már MELICH JÁNOS (1913) és HORGER ANTAL (1931) is. Ez utóbbi két szerző kivételével a nyelvmüvelő munkákat nem számítva nyelvészek hosszú ideig alig foglalkoztak a kérdéssel, csak az élőnyelvi kutatások kapcsán került újra látókörükbe (pl. KONTRA 1991b, KONTRA-VÁRADI 1991, BALOGH 1997, KASSAI 1998, CSERNICSKÓ 2002, KONTRA szerk. 2003, VARGHA 2007).

Szociolingvisztikai szempontból indokolt egy suksükölő és egy szukszükölő változó elkülönítése, történetileg és nyelvjárástörténetileg viszont a két típust nem könnyü szétválasztani. A történeti forrásokban az erre a nyelvi jelenségre vonatkozó írott adatok olyan ritkák, hogy egy szövegben csak egy-egy adat bukkan föl, a nyelvjárási gyüjtésekben pedig a legtöbb esetben nem kérdeztek rá külön a $m g h / m s h+t$ és a $m g h+s z t$ végü igékre, így többnyire csak a suksükölö adatokra lehet támaszkodni, és a nyelvatlaszok nagy részében is csak suksükölö igealakokra találunk példát (vö. SINKOVICS 2010).

A nyelvészek már a 19. század végén fölfigyeltek a szóban forgó jelenségre, minden bizonnyal azért, mert az 1870-es évektől megszaporodnak a nyelvjárási leírások, és ezt a ragozási sajátságot is sokfelé rögzítik. SIMONYI, majd HORGER mutatott rá arra, hogy ez egy teljesen természetes analógiás alakulás, hiszen a $t$ végüek kivételével a legtöbb mély hangrendü ige egyes szám harmadik személyü és többes szám első, második és harmadik személyü, valamint a magas hangrendủek többes szám első személyü felszólító módú alakjai azonosak a megfelelő kijelentő módú határozott alakokkal, ezek analógiájára pedig a $t$ végü igék is könnyen fölvették a felszólító mód mellé a kijelentő jelentést (SIMONYI 1895: 618, HORGER 1931: 137-138, lásd még ZOLNAI 1889: 22).

Az ösmagyar és ómagyar kori különféle változások azt eredményezték, hogy az igék jelentős részében a felszólító mód és a határozott ragozás kijelentő módja egybeesett minden olyan esetben, amelyben a határozott személyrag tartalmazta a $j$-t (lásd E. ABAFFY 1991: 142, 1992: 140-144, 191-192, 2003: 311). Kivételt képeznek ez alól a $t$ végü igék, mivel a $t+j$ összeolvadás a felszólító módban már az ősmagyar korban megtörtént, és hangkörnyezettől függően hol hosszú ss, hol hosszú ccs lett az eredmény (a részleteket lásd FORGÁCs 2001: 371-375). A határozott ragozásban azonban az összeolvadás csak az ómagyar korban ment végbe, és a $t+j$ kapcsolat összeolvadása magánhangzóközi helyzetben ekkor már nem hosszú $s s$-et, hanem hosszú tty-t eredményezett (vö. bottya, akarattya, illetőleg láttyuk, tanittyuk). Ezzel magyarázható a felszólító és a kijelentő mód közötti eltérés, a lássuk láttyuk, taníccsuk tanittyuk kettősség.

A $t$ végü igéknek ez a kivételes viselkedése analógiás hatásra több nyelvváltozatban kezdett eltünni. Mivel a legtöbb ige azonos alakú határozott ragozás kijelentő és felszólító módban (várja, mossa, mondja stb.), így a kivételes viselkedésű $t$ végüek esetében is a felszólító móddal alakilag egyező formákat kezdtek használni. Vagyis ha a magyar igeragozás történetét nézzük, akkor a suksükölés „a nyelv belső egyszerüsödési folyamata”, amely az igeragozásban az ősmagyar 
kortól napjainkig tart (HEGEDÜs 2005: 133). ${ }^{1}$ Legújabban KÁDÁR EDIT vetette föl, hogy kialakulásához az is hozzájárulhatott, hogy a felszólító móddal alakilag egyező kötőmód átterjedt más kontextusokra. Számos példát elemezve meggyőzően érvel amellett, hogy a székely és a moldvai csángó nyelvváltozatok esetében ezt a folyamatot a román nyelvi hatás erősíthette (2014: 65-72).

Nehéz megmondani, hogy a $t$ végü igéket érintő egyszerüsödés mikor kezdődött, eddigi kutatásaim alapján feltételezhető, hogy mind a suksükölő, mind a szukszükölö formák az írásbeliség normáján kívülre kerültek, a 18. század vége előttről ugyanis mindössze néhány példa van erre a nyelvi formára. Az elsőt SIMONYI a Székely oklevéltárból közli 1555-ből, a székely nemzeti gyülés által összeírt törvények szövegéböl: ${ }^{2}$ idegennek semmijét el ne m adhas sa, sem el nem vallhatja (SzO. 2: 121, SIMONYI 1895: 619, SzT. 5: 418b). ${ }^{3}$ A másikat először MELICH közli a Döbrentei-kódexböl: ${ }^{4}$ Azertes ki a le y l a magat allania. laffa hog ne effek (DöbrK. 361, MELICH 1913: 109, vö. E. ABAFFY 1992: 213). A Simonyi által fellelt adat arra utal, hogy a jelenség nem új keletü, és hogy már akkor is variábilis volt a két forma, hiszen egy mondaton belül szerepel egy suksükölö és egy nem suksükölö igealak: sem el nem adhassa sem el nem vallhatja. Ugyanebből az időből származik egy — a 20. századot megelőzően eddig egyetlen - hiperkorrekt alak: 1557: kerem $k$. hogy $k$. zabadet thya me gy zegenynek banffy wramtwl barmath (TERBE 2013: 171).

Az Erdélyi magyar szótörténeti tárban suksükölő adatra lehet ugyan bukkanni a 16-17. századból, ${ }^{5}$ de a $t$ végú igék szócikkeiben az igen gyakori ty-s formák mellett feltünően kis számban, és a példák egy része kötőmódként is értelmezhetö: 1571: és istrángot hoztanak ele kyvel fel akazzak, fel akaztasara harangoztanak (SzT. 3: 845a), ${ }^{6}$ 1637: Faszerzambol attunk elöben az kett Aruanak az kiben

${ }^{1}$ HegedŰs ATTILA arra is felhívja a figyelmet, hogy a kijelentő és a felszólító mód közötti analógiás kiegyenlítődést más esetekben is megfigyelhetjük, és nyelvjárási szövegközlésekből idéz adatokat arra, hogy kijelentő módban a felszólítóval egyező formákat használtak az adatközlők: kijelentő módú sürüzze, ritkázza, kivigyük stb. (2005: 132-133). A nyelvatlaszok adatainak e szempontból való áttekintését lásd SiNKOVICS 2010.

${ }^{2}$ A székely nemzetnek a törvénykezést és igazságszolgáltatást illető régi szokásos törvényei, melyeket a székely nemzeti gyülés összeírt, s Kendi Ferenc és Dobó István erdélyi vajdáknak bemutatván azok által megerősíttetett. Székelyudvarhely, 1555. április 28. A 19. század eleji kiadások a vonatkozó részt másolatokból és különbözőképpen közlik (RUMY 1817: 329, VAJDA 1830: 253), de a vélhetöleg az eredetiből kiadott változatban „el nem adhassa” áll (SzÉKELY 1818: 43).

${ }^{3}$ A Szótörténeti tár egy másik helyen más formában idézi: semmijét el ne adhassa (SzT. 1: 87).

${ }^{4}$ A Döbrentei-kódex az egyik első $i$-ző nyelvemlék, másolója, Halábori Bertalan Bereg vármegyéből származik.

${ }^{5}$ A gyakorisági szótárak (SzGySz., ÚGySz.) alapján a 40 leggyakoribb $t$ végü igét, ezek -hat/-het és -tat/-tet képzős alakjait és a be, $k i, e l, m e g$, fel, le igekötős változataik szócikkeit néztem át.

${ }^{6}$ A tágabb szövegkörnyezet: es istrangot hoztanak ele kijvel fel akazzak, fel akaztassara harangoztanak, akaztanij indultak vele, es keozben attijaffiai sok keonijergessel zabaditottak meg (SzO. 2: 325-326). 
feier Ruhaiokat tarcsyak Egy Eoregh fekü regi feier ladat (Kolozsvár, SzT. 12: 942a). Utóbbi két példában a tartsák lehetne kötőmódú is, ha a kötőszó (kivel és az kiben) a hogy azzal, illetőleg hogy abban szerepében áll. 1672: a Czehet jo modgyaval tudhassak gubernalni es gongyat viselni (Dés, SzT. 13: 603a). 1692: hüti sem tartotta azt hogy ollyan embert haborgasson annak marhajat hajcsa be a ki a' maga földen kötelen tarcsa marhajat (Dés, SzT. 12: 950a). Megjegyzendö, hogy a tartsa ige itt is mellékmondatban fordul elö.

Kétségtelenül a legérdekesebb egy 1624-ből származó adat. ${ }^{7}$ Egy nyelvkönyv hátsó kötéstáblájára székely betűkkel magyar szöveget írt a tulajdonosa. A bejegyzés olvasata: Ez tüke Farkaslaki Mátyásé, ez az könyő. Ha ki ellopja, felakasszák (SÁNDOR K. 2014: 247). A felakasszák szó az eddig ismert legkorábbi biztosan szukszükölö adat (SÁNDOR K. 2014: 248), saját gyüjtésemben a következő (az 1571-es mellékmondatbeli kyvel fel akazzak kivételével) majdnem száz évvel későbbről, 1717-ből való: A sövényfalvi Gáton és malmon aloll levő magyar és oláh szerben levö fundusokban hova való gát dagassza, tolja fel a vizet (Sövényfalva, SzT. 3: 871a).

A suksükölö alakok írott szövegekben a 18. század vége előtt rendkívül ritkán fordulnak elő, ${ }^{8}$ mivel azonban a 19. századi nyelvjárási adatok alapján Erdélyben és a Szeged környéki nyelvjárásokban általánosnak mondják, és meglehetősen nagy területen volt már használatos akkoriban is, feltehetően korábban keletkezett. Az, hogy írott szövegekben nem fordul elö, magyarázható azzal, hogy már korábban is stigmatizált lehetett, de az is lehetséges, hogy olyan nyelvi változóról van szó, amely a szóbeliségben nem volt stigmatizált, de az írott nyelvi normán kívül esett.

\section{Nyelvjárástörténet}

Eddigi ismereteink szerint először GYARMATHI SÁMUEL említi Nyelvmesterében mint a székely nyelvjárás sajátosságát: „Lássa ked komé, hogy Panna nem mene ám Están bátyhoz az az Látja kegyelmed komám uram hogy Anna nem mene István Bátyámhoz" (1794/2: 77, nem idézi, csupán hivatkozza SIMONYI 1895: 619). A lássa itt más feltűnő nyelvjárási sajátosságokkal együtt fordul elő, ez pedig arra utal, hogy GYARMATHI szerint azok használják, akik erősen nyelvjárásiasan beszélnek. KRIZA JÁNOS a Vadrózsákhoz készített jegyzeteiben azt

${ }^{7}$ Köszönöm Sándor Klárának, hogy felhívta erre az adatra a figyelmemet.

${ }^{8}$ A fentebb idézetteken kívül az 1700-as évekből összesen még további három adatra bukkantam: 1748: Csak a Patak válaszsza el a Kantától (SzT. 3: 66a), 1761: Szánto Földet [...] az eke út válossza meg, 1775: Északról az Málnási Erdotŏl válaszsza meg az Heresz pataka (SzT. 8: 1262a). Sem suksükölö, sem szukszükölő alakot nem találtam az udvarhelyszéki törvénykezési jegyzőkönyvekben (1569-1600, SzOkl. 1-3), sem a magyarországi boszorkányperek Csongrád megyéből (SCHRAM 1970: 225-347) és az erdélyi vármegyékből származó irataiban (BESSENYEI szerk. 1997, 2000, KISS-PÁLANTAL szerk. 2001). 
írja, hogy az egész székelység a $t$ végü igéknél a felszólító módot használja kijelentő mód helyett minden olyan esetben, amikor a ragban a $j$ elem megjelenik: lássa, lássuk, lássátok, lássák, illetve üssük (1863: 555), s megemlékezik arról is, hogy a csíki-gyergyói az eszik, iszik, vesz, visz, tesz, hisz igéknél is így jár el: nem igyam meg, nem vigyem el (1863: 557). RUBINYI MÓZES a moldvai csángók nyelvjárásának bemutatása során írja azt, hogy a $t$ végü igék kijelentő módjában a felszólító mód használata általános, „teljesen kiszorította a köznyelvi alakot” (1901: 114). Ezt megerősítik a moldvai csángó nyelvatlasz adatai is. A standarddal egyező forma csak néhány kutatóponton tünik föl, mindenhol suksükölö alakok mellett egy-egy adatként, egyébként a kijelentő mód határozott ragozás mindenhol egybeesik a felszólító mód határozott ragozású alakokkal (MCsNyA.).

A Magyar Nyelvészetben és a Magyar Nyelvőrben a 19. században megszaporodó nyelvjárási adatközlések Erdélyen kívül is egyre több helyről adatolják ezt a ragozási sajátságot. A magyar nyelvjárások osztályozása és jellemzése címü monográfiájában BALASSA JÓZSEF (1891) azt írja, hogy „,néhány nyelvjárás” a $t$ végü igék felszólító módú alakjait használja kijelentő módban. Erdélyen kívül a jelenség gócpontjaként a Szeged vidéki nyelvjárást nevezi meg, szerinte innen már a 18. században átterjedhetett a Temesközbe ${ }^{9}$ és a Dráva vidékére. KÁLMÁNYra hivatkozva BALASSA azt írja, hogy Szegeden a nép „küzd a kétféle ejtéssel", az irodalmi forma mellett megvan a másik változat is, de az irodalmi a győztes (1891: 51). ${ }^{10}$ BALASSA szerint Csanád, Békés, Csongrád megyékben szintén megtalálható ez a jelenség, Hódmezővásárhelyen azonban már nem (51), és a Duna-Tisza közén csak a Bács megyei nyelvjárásban van meg (62-63).

Az is figyelemre méltó, amit a drávaközi nyelvjárásokról ír BALASSA. A sárközi, az alsódrávai és a felsődrávai, valamint a szlavóniai nyelvjárásban is használják a felszólító alakokat kijelentő módban. Példái között azonban nemcsak a hazavigyük, a diót verjünk, engeggye található meg, hanem a lássa, roncsa, taníccsák is, habár BALASSA szerint a mélyhangú igéket ott úgy ragozzák, hogy ránti, huzi, adi (1891: 52, 54, 57). Ez azt mutathatja, hogy mindkét alak (ti. a ránti és a ráncsa is) használatos kijelentő módban. ${ }^{11}$ BALASSA szerint megtalálható a suksükölés a mátyusföldi és a csallóközi nyelvjárásban (92), valamint elöfordul a Hernád vidékén (87). Fejér megyében már kezd terjedni, de még nem mondható általánosnak (43). A székely nyelvjárás általános ismertetésénél

${ }^{9}$ Ez a „szegedi kirajzás” területe, a török visszaszorítása után a Délvidék számos települését népesítették be Szegedröl.

${ }^{10}$ KÁLMÁNY az idézett helyen csupán annyit ír, hogy Szegeden két nyelvjárás keveredik, és talán a kijelentő mód határozott ragozású alakok alapján lehet őket elkülöníteni, de ezt szerinte még további adatgyüjtéssel kellene tisztázni (1882: 231).

${ }^{11}$ Analógiás hatás itt nem érvényesül. Az utalhat a suksükölés földrajzi terjedésére, hogy a különböző formák egymás mellett voltak használatosak, vagy arra, hogy az adatok, a feljegyzések nem pontosak. 
szintén kiemeli ezt a sajátságot (100-101), de a marosszéki nyelvjárás jellemzésekor már azt írja, hogy ritkán használja a felszólítót a kijelentő mód helyett, gyakoribb a (standarddal egyezö) láttya, rontya, tanittyuk forma (102). SIMONYI 1895-ben, a Tüzetes magyar nyelvtanban BALASSÁt szó szerint idézi, de Fejér megye után zárójelben közbeszúrja: „és Veszprém megyében” (SIMONYI 1895: 619). 1934-es nyelvjárástanában HORGER már a következőképpen fogalmaz: „,[A magyar ige] némely tárgyas ragozású felszólító alakjai a magyar nyelvterület legnagyobb részének nyelvjárásaiban e funkciójukon kívül még jelentő módú funkcióban is használatosak [...] A magyar nyelvterületnek talán csak legészakibb sávján (kb. Máramarosszigettől Pozsonyig) és Dunántúl északnyugati részén nincsen meg" (1934: 136-137).

A 20. század elején a városok nyelvében is megjelent. Erre utal legalábbis az, hogy KEMENES PÁL a nyelvjárásoktól független budapesti nyelvi sajátságnak tartja az ,úgy is tudhassa, mit csináljon [...] nem láthassa [...] tanitsa" alakokat (1916: 375). KAIBLINGER FÜLÖP polgári iskolai szakfelügyelőként az 1910-es években Budapest perifériáján hallotta sokszor: Péter kinyissa az ajtót (1954: 150). Szintén a városi alsó rétegek nyelvhasználatára jellemző sajátságként jelenik meg Szép Ernő Lila ákácában (1919), amelyben Tóth Manci (varrónő, táncosnö) beszédét a mér, belegyön, aztat, szokok, mink mellett a lássa, tudhassa alakokkal illusztrálja az író (1975). ${ }^{12}$

A szépirodalomban a suksükölés először a színmüvekben jelentkezik. A reformkor nyelvéről írva TOMPA JÓzSEF csupán egy adatot talált: „,a’ [...] kamatot mingyárt ki vessük" Kovács Pál Thália címü munkájában (Kovács 1833: 178, idézi TOMPA 1955: 366), a szerzőnél máshol nem fordul elő ez a változat. A 19. század végén SIMONYI ZSIGMOND (1895: 618) azt írja, hogy „a népszinmü útján már-már behatolnak az irodalomba is".

KOVALOVSZKY MiKLÓS több munkájában tárgyalta a suksükölést, a története kapcsán számos példát idézett szépirodalmi müvekből, de az ide vonatkozó dolgozataiban felsorolt példáinak túlnyomó többsége nem a suksükölés körébe tartozik, hanem csupán arra adat, hogy felszólító módú igealakokat kijelentő mondatokban is lehet használni (1977: 209). KovALOVSZKY idéz suksükölö adatokat Móra Ferenc és Móricz Zsigmond müveiből is, de mindig csak párbeszédből, amint fogalmaz: „népi alakok beszéltetésében”. Ettől kezdve azután már megjelenik a szépirodalomban is, mint „népi beszédsajátság” (1977: 208, erre lásd még SIMONYI 1919: 81). Vagyis az 1910-es években az írók is fölfedezték mint olyan nyelvi formát, amely alkalmas volt arra, hogy irodalmi alkotásokban a nyelvjárási beszédet, illetőleg a városi alsó rétegek nyelvhasználatát jellemezze.

${ }^{12}$ A regényről írt bírálatában SIMONYI ZsIGMOND, a Magyar Nyelvőr akkori főszerkesztője kiemeli, milyen jól használja fel a szerző a városi népnyelvi sajátosságokat, valamint a népnyelvi elemeket, köztük ezt: Így, nem lássa? (1919: 81). 
Az 1950-es évek nyelvjárási gyüjtései lényegében megerősítik azt, amit HoRGER ANTAL a suksükölésről írt. A magyar nyelvjárások atlasza négy térképlapon (486: szoptatja, 487: ringatja, 834: adhatjuk, 861: tanitja) mutatja be az adatokat. IMRE SAMU monográfiájában egy rövid bekezdést szentelt ennek a kérdésnek. Az adhatjuk adatai alapján azt állapította meg, hogy a suksükölés ,általános az ÓzdTiszafüred-Tisza-Bodrog határolta területen [...] Igen gyakori egy viszonylag keskeny sávon Szenctől Szolnokig [...] Gyakori Zala keleti, Somogy nyugati felében, a Sió-torkolattól délre eső részeken, Szeged vidékén, Erdély keleti felében, de elszórtan megjelenik máshol is" (1971: 325). Nagyjából ezt mutatja a másik három térképlap is, de Somogyban és Zalában taníccsa, szoptassa adatok egyetlen kutatóponton sincsenek, a ringassa is csak Hahótról (B-21) adatolható, és e két szó suksükölő alakjai más területeken is jóval ritkábban fordulnak elő. Érdemes összevetni az adhatjuk térképét a tanitja és a tanitsa szóéval. A SzolnokÓzd-Tiszafüred-Tisza határolta területen (ahol az adhassuk adatok gyakoriak) a standard tanittya mellett a taníti és a tanijja formát gyüjtötték föl. Vagyis a felszólító mód és a kijelentő mód kiegyenlítődése a $t$ végü igék esetében ugyanúgy megtörtént itt is, mint máshol, csak épp eltérő módon, hiszen ezen a területen az -it végü igék felszólító módjában hosszú jj áll. A taníjja felszólító módú alak mellett a határozott ragozásban nem a standard tanittya — vagy a még várható taníjja - formát, hanem a taníccsa alakot jegyezték föl Vénekröl (C-3), Nagyivánról (M-15), Jászladányból (J-17), Szinpetriből (L-1), Szuhogyról (L-5), Debrétéről (L-7), Mélykútról (K-10), Dávodról (G-13), ez pedig feltehetőleg a többi $t$ végü ige suksükölő ragozásának analógiás hatásával magyarázható, vagy akár a suksükölés terjedésének is lehet a következménye (vö. VARGHA 2007: 281).

MURÁDIN LÁSZLÓ A romániai magyar nyelvjárások atlaszának kéziratos anyaga alapján azt állapította meg, hogy a moldvai csángóknál általános a suksükölés, mint ahogy a székely nyelvjárásokban is, kivéve az udvarhelyszéki falvakat, ahol némi ingadozás figyelhető meg. A mezőségi nyelvjárásban csak néhány suksükölő adat van, a szamosháti, bihari, kalotaszegi, szilágysági kutatópontokon nincs. Feltünő az is, hogy Kolozsváron az alsóbb nyelvi szinteken általánosnak mondható, de a környékbeli falvakban nincs meg (1992: 62).

A nyelvjárásokban a 20. század folyamán tovább terjedt a suksükölés. BALOGH LAJOS mutatott rá arra, hogy a nyugat-dunántúli nyelvjárásokban nem volt meg, csak viszonylag újabban terjedt el, „valószínüleg felülröl jött hatásként”. KISS JENŐnek Mihályiból közölt adatait idézi, ott ugyanis az 1950-es években kezdett terjedni (BALOGH 1997: 355). KISS JENŐ szerint Mihályiban az 1970-es években az idősebbek nyelvhasználatára alig jellemző, inkább a fiatalokéra, az 1980-as években már minden korosztálynak van suksükölő tagja, leggyakoribb a középgenerációnál, de még ott is kisebbségben vannak a suksükölők (1990: 40). Az újabb nyelvjárási gyüjtések a suksükölés és a szukszükölés megjelenéséről 
számolnak be olyan területeken, ahonnan korábban nem jegyezték föl. SÁNDOR ANNA Kolonban tapasztalta azt, hogy a középkorúak és a fiatalok nyelvhasználatában hallható suksükölés (az 1970-es években kezdett terjedni), de az idősebbeknél csak ritkán (2000: 97). A kijelentő módú lássa, taníccsa típusú adatok az összes szlovákiai magyar nyelvjárási régióban megfigyelhetők, „még ott is, ahol régebben nem volt jelen" (2009: 96). VARGHA FRUZSINA SÁRA azt állapította meg A magyar nyelvjárások atlasza ellenőrző gyüjtése alapján, hogy Lipóton „a fiatalabbak hajlamosabbak a csukcsükölő és suksükölő alakok használatára" (2007: 281).

A suksükölés nem lehetett kizárólagos egyik területen sem, csupán az egyik változat, a nyelvjárási gyüjtők ugyanis több esetben tesznek kiegészítő megszorításokat a suksükölés használatára. Erre utalnak a következő megfogalmazások: „némely tárgyas ragozású” (HORGER 1934: 136), Abaúj megye Füzéri járásában „gyakran egybeesik” a két alak (SzEMKŐ 1904: 41), Baranya megye Szentlőrinci járásában „egyik-másik igét” suksükölve ragozzák (SOMSSICH 1898: 209). (Lásd még KúNOS 1880: 204, ZOLNAI 1891: 84, GENCSY 1905: 41.) BALOGH LAJOS aZ MNyA. adataiból készített statisztikai összesítés alapján arra hívta fel a figyelmet, hogy a suksükölés a nyelvjárásokban nem olyan általános, mint korábban gondolták (1997: 359-360). Ráadásul több tényező potenciálisan csökkenti hatókörét, mint a némely nyelvjárásban a határozott ragozásban jelentkező láti, látitok ragcsoport; a középpalóc -uk/-ük ragpár (T/1: látuk) vagy az -it képzős igék taníjjuk típusú felszólító módja (1997: 356).

A nyelvjárási irodalmat áttekintve úgy látszik, hogy a suksükölés eredetileg a Székelyföldön és Szeged környékén jelent meg. A jelenségnek a moldvai csángóknál való megléte a székely kitelepüléssel is összefüggésben lehet, de akár román nyelvi hatásra is kialakulhatott. Szeged környékéről terjedt el a szegedi kirajzás következtében a Délvidékre, majd egyre északabbra és nyugatabbra a Dunántúlon. A 19. század végétől a városokba áramló vidéki munkásréteg révén jelenhetett meg a városok nyelvében, és vált a városi alsóbb társadalmi rétegek nyelvi sajátosságává. ${ }^{13} \mathrm{~A}$ kezdeti elítélő vélemények az alsóbb munkásrétegekhez kötik, és a szépirodalomban is népi tárgyú elbeszélésekben, illetőleg városi alsó rétegek nyelvi sajátságaként jelenik meg. Ezek közvetítésével terjedhetett el a 20. században olyan nyelvjárásterületekre - így például a magyar nyelvterület északi részeire -, ahol korábban nem volt adatolható. ${ }^{14}$

\footnotetext{
${ }^{13}$ HEGEDŰs ATTILA úgy véli, hogy a suksükölő igeragozásnak jelentős nyelvjárási háttere van, és talán azok közé a jelenségek közé tartozik, amelyek a nyelvjárási használatból kerültek a köznyelvbe (2005). Bár a suksükölő igeragozás nagy területen megtalálható, a fentiek alapján mégsem tartom valószínünek, hogy a nyelvjárásokból közvetlenül került be a standardba.

${ }^{14}$ KÁDÁR EDIT „másodlagos suksükölésnek” nevezi ezt a jelenséget (2014: 65).
} 


\section{A mai nyelvhasználat}

A suksükölő és szukszükölő ragozás elterjedtségéről a 20. század végétől már szociolingvisztikai felmérések eredményei is rendelkezésünkre állnak. A Magyar Nemzeti Szociolingvisztikai Vizsgálatban (MNSZV, 1988) több különböző feladattal vizsgálták a suksükölést, így szóbeli mondatkiegészítéssel és mondatmegítéléssel is. A suksükölő mondatot a megkérdezettek közel 30\%-a ítélte helyesnek (NY11: Ha idöben érkeznek, még ök is láthassák a filmet; NY202: Ha halkan beszélsz, senki sem hallhassa, mit mondasz). Az iskolázottság növekedésével a tesztmondatokat helyesnek ítélők aránya csökkent, vagyis nőtt a standard válaszok száma. A fővárosiak több standard választ adtak, mint a vidékiek, és a nyelvmüvelő müsorokat hallgatók és ilyen újságcikkeket olvasók is több standarddal egyező választ adtak. A szóbeli mondatkiegészítéses feladatban suksükölő választ a megkérdezettek mindössze 7-8\%-a adott (KONTRA 2003b: 131-134). Az MNSZV-ben a szukszükölést külön tesztmondatokkal vizsgálták. Az NY109: Nem szeretem, ha elhalasszák a döntést mondatot az adatközlők 56,5\%-a helyesnek ítélte, a szóbeli mondatkiegészítésben viszont 18-19\%-uk adott nemstandard válaszokat. Mindkét feladattípusban az iskolázottság növekedésével a standard válaszok száma nő (KONTRA 2003b: 135-139).

Ennek a kérdőíves vizsgálatnak az alapján KONTRA MIKLÓS arra mutatott rá, hogy a $t$ végü igék két típusát, a $t$ és az szt végủeket, azaz a suksükölö és a szukszükölő formákat el kell egymástól különíteni. Az MNSZV adatai szerint a suksükölés és a szukszükölés nem feltétlenül ugyanarra a beszélöre jellemző. Az eredmények azt mutatják, hogy aki suksüköl, az szukszüköl is, de fordítva ez nem így van, aki szukszüköl, az nem feltétlenül suksüköl. A különbséget az magyarázhatja, hogy a fonológiai hasonlóság különböző mértékủ a két esetben a standard és a nemstandard szóalak között. Az szt végü igéknél mind a standard, mind a nemstandard változatban van $s z$ [halasztyuk] és [halasszuk], míg a magánhangzó $+t$ tövüek esetén nagyobb a fonológiai különbség: [arattyuk] és [arassuk], ezért az utóbbi esetben a nemstandard jelleg feltünőbb (2003b: 137-139).

A szomszédos államokban élő magyarok körében végzett vizsgálatok az MNSZV-hez hasonló eredményeket mutattak. Írásbeli mondatkiegészítésben (pl. Ha Péter rosszul váloga ... meg a barátait, pórul jár. Minek ez a halogatás? Nem szeretem, ha valaki elhala ... a döntéseket.) jóval többen írták a szukszükölő változatot, mint a suksükölöt (lásd 1. ábra). A válaszok alapján vannak standard beszélök; vannak olyanok, akik szukszükölnek, de nem suksükölnek; és vannak olyanok, akik suksükölnek és szukszükölnek is (CSERNICSKÓ 1998: 277, 279 281, GÖNCZ 1999: 196-197, 259-260, 262, LANSTYÁK 2000: 323, 325-327, SZÉPFALUSI-VÖRÖS-BEREGSZÁSZI-KONTRA 2012: 138-139, 222-223, 297298, 300, FANCSALY és mtsai 2016: 197-198, 261-262). Ezek alapján ezt országhatároktól független egyetemes magyar változónak tekinthetjük. (A különbözö 
felmérések összevetését, — különös tekintettel Kárpátaljára — részletesen elemzi CSERNICSKÓ 2002.)

\begin{tabular}{|l|c|c|c|c|}
\hline & válogatja & válogassa & elhalasztja & elhalassza \\
\hline Szlovénia & $98,3 \%$ & $1,7 \%$ & $78,6 \%$ & $21,4 \%$ \\
\hline Jugoszlávia (Vajdaság) & $97,6 \%$ & $2,4 \%$ & $91,3 \%$ & $8,7 \%$ \\
\hline Magyarország & $96 \%$ & $4 \%$ & $84,3 \%$ & $15,7 \%$ \\
\hline Ausztria & $95 \%$ & $5 \%$ & $71,4 \%$ & $28,6 \%$ \\
\hline Románia & $91,4 \%$ & $8,6 \%$ & $71,1 \%$ & $28,9 \%$ \\
\hline Horvátország & $87,9 \%$ & $12,1 \%$ & $78 \%$ & $22 \%$ \\
\hline Szlovákia & $87,7 \%$ & $12,3 \%$ & $66 \%$ & $34 \%$ \\
\hline Ukrajna (Kárpátalja) & $78,3 \%$ & $21,7 \%$ & $47,9 \%$ & $52,1 \%$ \\
\hline
\end{tabular}

1. ábra. Suksükölő és szukszükölő mondat írásbeli kiegészítése

(CSERNICSKÓ 1998, GÖNCZ 1999, LANSTYÁK 2000, SZÉPFALUSI-VÖRÖS-BEREGSZÁSZIKONTRA 2012 és FANCSALY és mtsai 2016 alapján)

\section{A nyelvi szabályozás}

A nyelvmüvelő munkákban viszonylag későn teszik szóvá e ragozási sajátságot. SIMONYI ugyan a Tárgyas alakok összezavarása az imperativussal cím alatt már foglalkozik a kérdéssel Tüzetes magyar nyelvtanában, de a következő félmondatán kívül: „a népszinmü útján már-már behatolnak az irodalomba is az ilyenféle alakok: nem tudhassuk stb." nem találunk elítélő megjegyzést nála (1895: 617).

Eddigi adataim szerint írásban először 1916-ban találkozunk a jelenség megítélésével: a Magyar Nyelv Levélszekrény rovatában KEMENES PÁL írja, hogy a nyelvjárásokban sokfelé előfordul, hogy a $t$ végü és az $s z \sim v$ tövü igéket a kijelentő módban is felszólító módú alakjukban használják. „Úgy gondolom — írja KEMENES -, hogy e jelenségtöl függetlenül keletkezett a budapesti nyelvben egy hasonló használat. Gyakran lehet hallani - $\mathrm{s}$ min t $\mathrm{megfigye} 1 \mathrm{te} \mathrm{m}$ — túlnyomó a n tré fából, d e komolyan is [ritkítás tőlem: S. B.] ilyeneket: úgy is tudhassa, mit csináljon... nem láthassa ... tanitsa ... —Én e pesti használatban nem a nyelvjárások hatását, hanem ezektől független, eredetileg tréfából keletkezett használatot látok" (1916: 375). ${ }^{15}$

A suksükölö igeragozás 20. század eleji megítéléséről keveset tudunk. PÁLFI MÁRTON, kolozsvári fógimnáziumi tanár 1902-ben írja, hogy a falusi gyermek

${ }^{15}$ KovALOvSZKY a suksükölés első felbukkanását a standardban a Magyar Nyelv 1904-es évfolyamában megemlített engesse szabálytalan felszólító módhoz köti (1953a: 223). Mivel azonban ott az engesse egyértelmủen felszólító mód, az igealak nem a suksükölő ragozás kérdésköréhez tartozik, hanem a $t$ végú igék felszólító módjának analogikus hatására alakult nyelvjárási formák egyike. 
az iskolába kerülve szembesül azzal, hogy a tanító nem úgy beszél, ahogy ő odahaza hallotta. „Nem úgy mondja, hogy csidma, hanem csizma, nem kinyeret, hanem kenyeret mond. [...] Azt mondja hogy $b-a-b$ s rá kell mondani, hogy $b a b$. Ugy taniccsa, hogy tanítja, látja, mondja" (1902: 15). A tanítók által javított formák között a stigmatizált kijelentő módot is megemlíti. ${ }^{16}$ Egy másik adat KAIBLINGER FÜLÖP hozzászólása a Nyelvmüvelésünk főbb kérdései címü tanulmánygyüjtemény vitájában szintén erre az időszakra vonatkozik: „mint fóvárosi polgári iskolai szakfelügyelő (1912-1914) Budapest perifériáján sok helyen hallottam az ilyet: Péter kinyissa az ajtót. [...] Ök [a tanárok] ezeket buzgón javították, amit el is vártam" (1954: 150). PÁLFInak és KAIBLINGERnek ez a megjegyzése egyértelmúen arra utal, hogy a suksükölést az iskolákban a 20. század elején megbélyegezték és javították.

A 20. század első évtizedeinek fontosabb nyelvhelyességi könyveiben nem találtam utalást erre a jelenségre (vö. SIMONYI 1903, KELEMEN 1918, BALASSA 1922, KOSZTOLÁNYI szerk. 1933). A nyelvmüvelő irodalomban az 1930-as években tünik fel egyre gyakrabban. DÉNES SzILÁRD a Népoktatási Szemlében fejti ki, hogy a népiskolának az is feladata, hogy az otthonról hozott hibákat javítsa a diákok beszédében, és a hibák között (szabadott, kelletett, meg-e látod, ha nem is látod) felsorolja a meglássa, elossza alakokat is (1932: 33). A következő elítélő megállapítás 1933-ból, a Magyarosan címü nyelvmüvelő folyóiratból származik, egy ún. laikus nyelvmüvelőtől: „Nehány év óta nagyon elharapódzott a társalgás nyelvében, sőt a hírlapok nyelvébe is belopódzott az a népnyelvi jelenség, hogy a $t$, st, szt végú igék tárgyas ragozásában összekeverik a jelentő mód némely alakját a felszólító mód megfelelő alakjaival" (VÖÖNÉ PÉCS 1933: 114). NAGY J. BÉLA szerkesztő minden kritikai megjegyzést mellőzve ehhez csupán a következöt füzte: „Így van több nyelvjárásban (lásd Klemm: Magyar történeti mondattan 68). Az irodalmi nyelv kerüli ezt a használatot, de a mindennapi beszédben szoktuk mondani kedélyes hangon: nem lehessen tudni” (N. J. B. 1933: 115).

Ezután csak futólag említik mint nyelvhelyességi hibát (pl. TAKÁTS 1935: 17). A Magyarosan 1937. évi számában ${ }^{17}$ azonban JUHÁSZ JENÖ Jaj, az a felszólító mód! címü háromoldalas írásában mutatja be és kárhoztatja a jelenséget. Elítélő szavai miatt különös az utolsó mondata: „Nehéz ugyan társalgás közben megállnunk s azon törnünk a fejünket, hogyan kell helyesen mondanunk az igealakot, de hát legalább írás közben álljunk meg és így törekedjünk az irodalmi nyelvü előadásra! [ritkítás tőlem: S. B.]" (JUHÁsz 1937:

${ }^{16}$ A folytatásban azt fejtegeti, hogy a lehető legrosszabb az, ha az iskola megutáltatja a gyermekkel a népnyelvet. Az iskola tanítsa meg ugyan az irodalmi nyelvet is, de közben ne üzzön gúnyt a népnyelvböl, hanem becsülje meg (PÁLFI 1902: 17-20). A dolgozatról egy részletes összefoglaló a Magyar Nyelvőrben is megjelent (TOLNAI 1903).

${ }^{17}$ Ebben az évben volt szerkesztőváltás, Szinnyei József és Zsirai Miklós helyett Pintér Jenő és Putnoky Imre lettek a szerkesztők, ekkortól válik rendkívül puristává a lap. 
143). Ez és NAGY J. BÉLA idézett megjegyzése legalábbis azt mutatja, hogy a nyelvmüvelés ekkor még nem ítélte meg olyan szigorúan a suksükölést, mint a tanítók és mint a laikus nyelvmüvelök; a kevésbé formális beszélt nyelvben, úgy tünik, megtürték.

Ugyancsak 1937-ben jelent meg DENGL JÁNOS Magyar nyelvhelyesség és magyar stílus címü könyve, ${ }^{18} \mathrm{~s}$ itt már a hibáztatott jelenségek között találjuk: „Újabban mindjobban elharapódzik — fökép az utca nyelvében — a fölszólító mód tárgyas alakjának a jelentő mód jelen ideje helyett való hibás használata, különösen a -t, -st, -szt tövü igék esetében, pl. az üzletet nem nyissák ki [kiemelés az eredetiben] 8 óra előtt (nyitják h.), nem válasszák meg (választják h.) [...] Ezeket a rút helytelenségeket nem lehet a nép nyelvével igazolni!" (1937: 134135). PINTÉR JENÖ nagy hatású Magyar nyelvvédő könyvébe szintén belekerült, igaz, szokásos tömörséggel, mindössze négy sorban hibáztatja a jelenséget: ne használjunk kijelentő mód helyett felszólítót a $t$, st, szt végü igék esetében (1938: 21). ${ }^{19}$ Ebben az évben jelent meg HALÁsz GYULA nyelvmüvelö könyve is, amelyben már erőteljesen megbélyegzi a suksükölést: „A műveltség fokmérője nem a szappanfogyasztás, hanem ezek az árulkodó igealakok: engesse, engessen. [...] Veszedelmesebbek a $t$-vel végződő igék, mert ezek a fölszólitó módban csakugyan elveszitik $t$-betüjüket és van ilyen $s$-betüs alakjuk: lásson [...] A felszólitó - ugynevezett parancsoló - módnak ezt az $s$ betüjét kezdik most belecsempészni a jelentő módba. Ez már veszedelmesebb járvány, mert irókra szinészekre is átragadt. Népiesnek érzik." (1938: 104) ${ }^{20}$ Ettől kezdve a nyelvhelyességi kézikönyvekben ugyan feltünik e ragozási jellegzetesség (pl. TISZAMARTI 1943: 1415), de a Magyarosan címü folyóirat vagy a Magyar Nyelvőr alig foglalkozik a kérdéssel. Még azokban a nyelvmüvelő cikkekben sem találtam nyomát a hibáztatásnak, amelyek kíméletlenül bírálják az írók, újságírók, hivatalnokok szövegeit. ${ }^{21}$

PINTÉR JENÖ nyelvvédő könyve igen népszerü volt, több tízezres példányszámban jelent meg, több kiadást megért, sőt a könyvben megfogalmazott szabályokat az iskolákban táblákon is terjesztették. Ezenkívül mint budapesti tankerületi főigazgató rendelettel tette kötelezővé a nyelvmüvelést; mindezek következtében hatása sokáig érezhető volt. Mivel HALÁSZ GYULA könyvében a

${ }^{18}$ Dengl János (1882-1940): nyelvész, egyetemi tanár, a kereskedelmi szakoktatás és a gyorsírás tanára a Múegyetemen.

${ }^{19}$ „A - $t$, -st, -szt végü igék jelentő módja helyett ne használjunk felszólító módot. — Helytelen: a fejezetet felosszuk három részre. Helyes: a fejezetet felosztjuk három részre."

${ }^{20}$ Halász Gyula könyvéröl írt bírálatában BALASSA JÓzSEF, a korszak egyik tekintélyes nyelvművelője a suksükölésről szóló részhez a következő megjegyzést tette: „Meg kellett volna említenie, hogy a nép több vidéken használja ezeket az igealakokat, tehát népies pongyolaság az irodalmi és köznyelvben" (1938: 82).

${ }^{21}$ Ennek az is lehet az oka, hogy a bírálatok többsége írott szövegeket kritizált, a suksükölés azonban föképpen a szóbeliségben létezett. 
rádióban már korábban megtartott nyelvmüvelő előadásait, illetve különböző lapokban megjelent írásait adta ki, nézetei terjedéséhez ez is jelentősen hozzájárulhatott. $^{22}$

\section{Suksükölés mint „nyelvi járvány”}

A második világháború után az újjászerveződő nyelvmüvelésnek viszont már a suksükölés az egyik központi kérdése lesz. 1953-ban KOVALOVSZKY MiKLÓS legalább három helyen (Magyar Nyelvőr, Nyelvmüvelésünk föbb kérdései címü kötet, rádióelöadás) foglalkozott a suksüköléssel (1953a, 1953b, 1956). Ettől kezdve a nyelvmüvelés egyik fontos feladata a suksükölés elleni harc.

Az új nyelvmüvelö hozzáállás KovAlOVSZKY MiKLós Magyar Nyelvőr-beli cikkében jelentkezik a legösszeszedettebben. Ennek már a címe is árulkodó: Egy új nyelvi járvány. Benne van mindaz, amit a későbbiekben a suksükölés ellen felhoznak a nyelvmüvelök. KovALOVSZKY szerint ez a felszabadulás utáni nagy népmozgások következtében vált általánossá, mivel ,a mozgalmi és szervezeti életben résztvevő hatalmas tömegek számára sok alkalom adódik élőszóbeli megnyilatkozásra, és ez járványszerüen terjeszti a suksük-nyelvet” (1953b: 224). Néhány sorral lejjebb azt írja: „Akik a suksük-nyelven beszélnek, azoknak nem hivatásuk vagy rögeszméjük a parancsolás, mégis mindig felszólító módot használnak. A hiba az, hogy nem érzik vagy nem ismerik a kijelentés és a felszólítás nyelvtani, alaki különbségét. [...] Akinek gyenge, nem eléggé tudatos a nyelvérzéke és kicsiny az olvasottsága, az könnyen beleesik ebbe a már gyakori hibába, még ha eredeti nyelvjárásában vagy gyermekkori nyelvhasználatában ismeretlen is az effajta ragozás." Hozzáteszi, hogy mások azért kezdenek így beszélni, mert ebben proletár igeragozást látnak, megint mások azért, mert így akarják csúfolni az új kádereket (1953a: 224-225, ehhez lásd még KONTRA 1991a). ${ }^{23}$

KOVALOVSZKY szerint nem szabad teret engedni az ilyenfajta igeragozásnak, mert az megbontaná az irodalmi nyelv egységét, és mert ezzel az igeragozási rendszer csak bonyolultabbá válik, ugyanis ,,az igéknek aránylag kis csoportjában ment végbe, $\mathrm{s}$ másutt nem igen lehetséges”, ráadásul a fiatalabbaknak gondot

\footnotetext{
${ }^{22}$ Könyvét 1991-ben újra kiadták, benne az idézett esszével. A kötet előszavában SzŰTs LÁszLÓ azt írja, hogy HALÁsz GYULA ostorozásai ma is időszerüek, a hibák nagy része ma is megvan; ezért csak azokat a részeket hagyta ki, amelyek már nem aktuálisak. Ezzel az újabb kiadással azt szeretnék elérni, hogy mindazokhoz eljussanak ezek az intelmek, akik az igényes nyelvhasználatra törekszenek (1991: 5).

${ }^{23}$ A Béke és szabadság című hetilap 1953. március 1-jei számából idézi a következőket: „Vannak, akik tudják, hogy hibás és helytelen a tudhassuk, láthassuk: mégis ezt használják, mert azt hiszik, hogy ezzel »tyü, de proletárok lettünk«, »hijnye, de paraszti sarjak vagyunk«. Erőszakolt és átlátszó álarc ez, mely gyanút kelt, cinizmusa visszataszító. Vannak azután olyanok is, akik ugyancsak tudják, hogy a tudhassuk, láthassuk helytelen, mégis minduntalan, sőt kacérkodva használják, mert ezzel egyet csípni akarnak, gúnyoskodni igyekeznek, hogy no most jól megadjuk az új kádereknek." (KovALOVSZKY 1953a: 225).
} 
okozna a klasszikusok olvasása (1953a: 226). Úgy vélem, itt szerepel először az a példamondat, amellyel a félreértést szemléltette: Mikorra halasszuk az értekezletet? A mondattal az a baj KoVALOVSZKY szerint, hogy nem dönthetö el, érdeklődik vagy tanácsot kér, aki így beszél. Megemlíti ugyan, hogy a mondat egésze és más nyelvtani eszközök általában egyértelmủvé teszik, hogy kijelentésröl vagy felszólításról van-e szó, de az ilyen és ehhez hasonló példák félrevezetőek lehetnek (1953a: 227).

KOVALOVSZKYnak ez a tanulmánya szinte változatlan formában belekerült a korszak meghatározó nyelvhelyességi kiadványaiba (1956, 1959, 1977). A Nyelvmüvelő címü kötetben pedig szinte megismétli HALÁsZ GYULA szavait: „Annyira elterjedt ma már ez a beszédsajátság, hogy amint régebben a szappanfogyasztást tekintették a civilizáltság fokmérőjének, a mai müvelt magyar nyelvhasználatot arról ítélhetjük meg, hogyan ragozza valaki az ilyen igéket" (KOVALOVSZKY 1956: 207)..$^{24}$

A Nyelvmüvelésünk főbb kérdései címü tanulmánygyüjtemény ${ }^{25}$ vitájában KAIBLINGER FÜLÖP hozzászólása és a rá adott válaszok különösen érdekesek. A következőket írja: ,a nyelvfejlődéssel foglalkozó tanulmányaim alapján úgy éreztem, hogy a - $t$ végü igék most szenvedik el azt a $\mathrm{k}$ i j e 1 e $\mathrm{n} \mathrm{t}$ ő - f e $1 \mathrm{~s}$ z ó lí t ó [kiemelés az eredetiben] egységesülést, amin az igék többsége — néhány rendhagyó kivételével (tegyem, alussza stb.) — már évszázadok óta rendszabályozás híján átesett; mélyhangú tudja, -juk, -játok, -ják; olvassa, -suk stb. stb., magashangú kérjük, keressük" (1954: 150). Nem fogadja el azt az érvelést, hogy nyelvi tudatlanságról van szó, vagyis hogy aki így beszél, az nem tudja a kijelentés és a felszólítás közötti különbséget; azt hangsúlyozza, hogy a kinyissa ebben a nyelvváltozatban kijelentő mód. A nyelv „gondoskodott differenciáló eszközökről”” (hanglejtés, szórend), és ezek az újabb esetben is rendelkezésre állnak. Ennek ellenére KAIBLINGER úgy véli, hogy harcolni kell ellene, méghozzá a nemzeti nyelv egysége érdekében (uo.). DEME LÁSZLÓ ugyanott megjelent válaszában élesen kritizálja ezt a hozzáállást: „Kaiblingernek még az elhangzottakhoz képest erősen megváltoztatott hozzászólásából is kiderül, hogy ő a suksük-nyelvet jobban szeretné megérteni és elfogadni, mint elítélni. Szélesen elterjedt nyelvtény, az igaz. De nem a nemzeti irodalmi nyelvben, amely a helyesség normája, hanem az igénytelen köznyelvben, meg a nyelvjárásokban, amelyek mégsem lehetnek a helyesség megítélésekor irányadók" (1954: 160).

DEME és KovALOVSZKY nézetei jól tükrözik azt a változást, amely a nyelvművelés állásfoglalásában bekövetkezett a suksükölés tekintetében. Az 1930-as években a nyelvmüvelés meghatározó alakjai, NAGY J. BÉLA, JUHÁSZ JENÖ

\footnotetext{
${ }^{24}$ A tanulmány végén az áll, hogy egy 1953 -as rádióelőadás alapján készült.

${ }^{25}$ Ebben a kötetben szintén KovALOVSZKY MIKLÓs írt röviden a suksükölésről (1953a: 192-196).
} 
vagy akár BALASSA JÓZSEF véleménye megengedő volt (legalábbis a szóbeli nyelvhasználatot illetően), és nem általában helytelenítik, nem tudatlanságból elkövetett hibának tartják, hanem csupán népiességnek, pongyolaságnak. Már ugyanekkor megjelenik azonban a másik, az elítélő álláspont (DENGL JÁNOS, PINTÉR JENŐ, TISZAMARTI ANTAL és mások), amely majd az 1945 után újjászerveződő nyelvmüvelésben tovább él, és az 1953 körül megjelenő alapvető fontosságú munkákban jelentős helyet foglal el. Ez az elutasító álláspont került be a korabeli középiskolai nyelvtankönyvekbe (SZEMERE 1954: 47, ${ }^{26}$ BENKÖ-KÁLMÁN 1954: 68), a segédkönyvekbe (RÁCZ-TAKÁCS 1974: 108-109) és az egyetemi tankönyvbe is (VELCSOVNÉ 1968: 181). A jelenséget az 1990 után megjelenő tankönyvek némelyike is hasonló szellemben tárgyalja (középiskola: SzENDE 1994: 68-69, ANTALNÉ DR. SZABÓ-RAÁTZ 2005: 79; felsőoktatás: BOKOR 2007: 280$){ }^{27}$

A Nyelvművelő kézikönyvben KovALOVSZKY „,a nyelvjárásokban és az alsóbbrendű köznyelvben" használt formának tartja, bemutatja a történetét, 20. századi terjedését és kialakulásának okait. Összegzésül pedig ezt írja: „Bár a »suksük«-ragozás nyelvtörténeti és társadalmi okokkal magyarázható természetes, analógiás fejlemény, nem tekintjük helyesnek. Söt még káros is, mert szegényíti a nyelvet: olyankor is elmossa a különbséget a közlés, valamint az óhaj és felszólítás közt, amikor — mármint a $t$ végü igékben — ezt a különbséget nyelvi eszközökkel is éreztethetjük" (1980: 618). Úgy véli, a nyelvmüvelés eredményes volt: „Az ötvenes évek elején megindult küzdelem eredményeként a hibás használat »divatja« visszaszorult, kivéve tán az -szt végű igék »szukszük «-ragozását, amely különösen makacsnak mutatkozik (felragasszuk, kirekesszük stb.)” (1980: 617). ${ }^{28}$

A Nyelvmüvelö kéziszótár szerint egyes nyelvjárásokban és a budapesti köznyelvben a $t$ végü igék felszólító módú alakjait kijelentő értelemben is használják.

${ }^{26}$ „....széltében-hosszában terjed az a helytelen beszédmód, amely bizonyos igék kijelentő módú alakjait felszólítókkal helyettesíti. Nagyon gyakran hallunk efféléket: »Nem bocsássuk meg nekik« (bocsátjuk helyett) [...] Küzdjünk e csunya nyelvi hiba ellen! [kiemelés az eredetiben]" (SzEMERE 1954: 47).

„Egyesek nyelvhasználatában keverednek az igemódok, főként a kijelento és a felszólító. Ez azonban minden esetben helytelen, hiszen az igemódok összezavarása beszédünk világosságát, érthetőségét veszélyezteti. Nem szabad tehát a kijelentő mód helyett felszólító módot használnunk. Különösen a t végü igékkel kapcsolatosan harapództak el az ilyen hibás mondatok: »Péter kinyissa az ajtót.«" (BENKÖ-KÁLMÁN 1954: 68).

27 „bizonyos nyelvjárásokban szokásos, de az alsóbb szintű köznyelvi használatban sem ritka. Az igényes köznyelvben azonban nincs helye” (SzENDE 1994: 68), és a munkafüzetben több feladat is gyakoroltatja a kerülését (SzENDE 1998: 66-67). Tankönyvükben ANTALNÉ DR. SZABÓ és RAÁTZ Félrecsúszott toldalékok cím alatt egy rövid bekezdésben tárgyalja és helyteleníti a suksükölést (2005: 79)

${ }^{28}$ GRÉTSY hívja fel a figyelmet először arra, hogy az szt végü igék másképpen viselkednek: „Mint példáimból is látható, mégsem annyira suksük-, mint inkább szukszük-ragozás ez” (1964: 243). 
Majd a szócikk szerzője ezt füzi hozzá: „A két igemód alaki megkülönböztetéséhez a közlés pontossága érdekében szigorúan ragaszkodnunk kell, tehát „,a »suksük«-, ill. »szukszük«-özésnek okvetlenül gátat kell vetni” (NymKsz. $\left.{ }^{2} 178\right){ }^{29} \mathrm{~A}$ szótárban a vulgáris stílus címszóban is felbukkan a suksükölés rendkívül megbélyegző szövegkörnyezetben: „A [vulgáris] stílus rombolja a választékos, müvelt érintkezést, $\mathrm{s}$ ezáltal nemcsak a nyelvi normák hatását gyöngíti, hanem az erkölcsi, magatartási, viselkedési normákét is. Nyelvi értéket pusztít a »suksük«nyelv, a mondatbeli egyeztetés hiánya, a suta szóismétlés — köztük a kötőszóké, módosítószóké - , de egyben gátolja az egymás megbecsülésén alapuló, csiszolt érintkezést, az emberi rokonszenvnek s általában a pozitív érzelmeknek a kifejezését" (NymKsz. ${ }^{2}$ 611).

A tanítói, tanári és a nyelvmüvelö tiltásoknak az lett a következménye, hogy a suksükölő ragozás az egyik legjobban megbélyegzett formává vált, és használóira az iskolázatlanság, tudatlanság bélyegét ragasztják a mai napig (vö. Story 2009, GEREBEN 2010, VIOLA 2012, SZÖNYI 2014, VERESS 2015).

\section{7. Összegzés}

A suksükölésről a 19. század első évtizedeit megelőzően csak elszórt adatok vannak. A különféle följegyzések és gyüjtések alapján föltehető, hogy már a 18. században is használatos volt a székely nyelvjárásokban és Szeged környékén. A suksükölés mint a kijelentő mód határozott ragozás egyik alakváltozata kezdetben még csupán indikátor lehetett. Az egyes nyelvjárásokban a kijelentő és felszólító mód között mutatkozó kiegyenlítődést az írott nyelv kirekesztette, és a standard a $t$ végü igék kivételességét fönntartotta. ${ }^{30}$ Vagyis ez a nyelvi forma egy ideig azok közé a nyelvi változók közé tartozott, amelyek a szóbeliségben jelen voltak, jelen vannak, de amelyek használatát az írott nyelv kerülte, a változó tehát indikátorból markerré vált.

Ha a suksükölő ragozás már a régebbi időkben is megbélyegzett lett volna, akkor esetleg hiperkorrekt alakoknak is föl kellene bukkanniuk, de egy nagyon korai kivételével nincs adat a 20. század közepe előtt a hiperkorrekcióra sem. Elöször KOVALOVSZKY hívja fel a figyelmet arra, hogy némelyek felszólító módú alakok helyett kijelentő módot használnak: „Vannak ma már olyan bizonytalankodó óvatosak is, akik, hogy elkerüljék a hibát, az ellenkezőbe esnek, s ilyeneket mondanak: Hallgatjuk csak meg!” (1953b: 192).

${ }^{29}$ Ez egyezik azzal a nyelvművelő alapelvvel, mely szerint ahol csak lehet, kerülni kell a homonimákat.

${ }^{30}$ Ugyanígy kirekesztette az írott nyelv a felszólító módban a tanijja-féle alakokat — a standard tanitsa formával szemben —, de ez nem vált stigmatizált változattá, hanem megmaradt nyelvjárási sajátságnak. 
A suksükölést a 20. század elején a tanárok már javították, bár lehet, hogy csak úgy, mint bármely más nyelvjárási sajátságot. Ebben az időben a szépirodalomban is megjelent a nyelvjárási és a városi alsóbb rétegekre jellemző beszéd egyik elemeként. Így könnyen összekapcsolódhatott a műveletlenséggel, mivel a nyelvjárási beszédet általában a kevésbé iskolázottak őrizték meg. HALÁsZ GYULA 1938-ban már egyértelmüen kimondja, hogy a suksükölés a müveltség fokméröje. A suksükölés így sztereotípiává vált, és nagyon sokan napjainkig úgy vélik, hogy használata a beszélö müveletlenségét mutatja.

\section{Irodalom}

E. ABAFFY ERZSÉBET 1991. Az igei személyragozás. In: BENKÖ LORÁND föszerk., A magyar nyelv történeti nyelvtana 1. A korai ómagyar kor és elözményei. Budapest, Akadémiai Kiadó. 122-159.

E. ABAFFY ERZSÉBET 1992. Az igemód- és igeidőrendszer; Az igei személyragozás. In: BENKÖ LORÁND föszerk., A magyar nyelv történeti nyelvtana 2/1. A kései ómagyar kor. Morfematika. Budapest, Akadémiai Kiadó. 120-183, 184-238.

E. ABAFFY ERZSÉBEt 2003. Hangtörténet. In: KisS JeNÖ-PUSZTAI FerENC szerk., Magyar nyelvtörténet. Budapest, Osiris. 301-351.

ANTALNÉ DR. SZABÓ ÁGNES-DR. RAÁTZ JUDIT 2005. Magyar nyelv és kommunikáció. Tankönyv a 11-12. évfolyam számára. Második, átdolgozott kiadás. Budapest, Nemzeti Tankönyvkiadó.

BALASSA JÓzSEF 1891. A magyar nyelvjárások osztályozása és jellemzése. Budapest. Magyar Tudományos Akadémia.

BALASSA JózSEF é. n. [1922]. Helyes magyarság. Budapest, Genius Könyvkiadó R. T.

BALASSA JÓZSEF 1938. Nyelvtisztaság és nyelvhelyesség. Magyar Nyelvőr 67: 77-86.

BALOGH LAJOS 1997. A magyar nyelvjárások és a suksükölés. Magyar Nyelv 93: 354-360.

BENKÖ LORÁND-KÁLMÁN BÉLA 1954. Magyar nyelvtan. A gimnáziumok I-IV. osztálya számára. Ötödik kiadás. Budapest, Tankönyvkiadó.

BESSENYEI JÓZSEF szerk. 1997-2000. A magyarországi boszorkányság forrásai 1-2. Budapest, Balassi.

BOKOR JÓZSEF 2007. Szóalaktan. In: A. JÁSzÓ ANNA szerk., A magyar nyelv könyve. Budapest, Trezor Kiadó. 254-292.

CSERNICSKÓ ISTVÁN 1998. A magyar nyelv Ukrajnában (Kárpátalján). Budapest, OsirisMTA Kisebbségkutató Mühely.

CSERNICSKÓ ISTVÁN 2002. A - $t$ végủ igék kijelentő módja mint egyetemes változó? Magyar Nyelv 98: 313-320.

DEME LÁszLÓ 1954. Hozzászólás a „Nyelvmüvelésünk főbb kérdései” címủ tanulmánygyüjtemény vitájához. Magyar Nyelvőr 78: 160.

DÉNES SZILÁRD 1932. A népiskola a nyelvhelyesség szolgálatában. Népoktatási Szemle 1: 32-35. 
DENGL JÁNOS 1937. Magyar nyelvhelyesség és magyar stílus. Budapest, Grill Károly könyvkiadóvállalata.

FÁBIÁN PÁL 1984. Nyelvmüvelésünk évszázadai. Budapest, Gondolat.

FANCSALY ÉVA-Gúti ERIKA-KONTRA MiKLÓs-MOLNÁR LJUBIĆ MóNIKA-OsZKÓ BEATRIX-SIKLÓSI BEÁTA-ŽAGAR SZENTESI ORSOLYA 2016. A magyar nyelv Horvátországban. Budapest-Eszék, Gondolat Kiadó-Media Hungarica Művelődési és Tájékoztatási Intézet.

FORGÁCS TAMÁS 2001. Die postalveolare Assimiliation - aus der Sicht der ungarischen Sprachgeschichte. Acta Linguistica Hungarica 48: 371-387.

GENCSY ISTVÁN 1905. A gyergyói nyelvjárás. Nyelvészeti Füzetek 20: 31-62.

GEREBEN ÁGNES [2010]. Fehér ember nem felejt! — Konzervatív-e vagy? In: Kun Miklós hírportál. URL: http://kunmiklos.com/hirek-kun-miklos/feher-ember-nem-felejtkonzervativ-e-vagy_4502_526121.html. (2013.augusztus 6.)

GÖNCZ LAJOS 1999. A magyar nyelv Jugoszláviában (Vajdaságban). Budapest-Újvidék, Osiris-Forum Kiadó.

GRÉTSY LÁSZLÓ 1964. Ami méltán ,,aggassza” az olvasókat. In: GRÉTSY LÁSZLÓ, Szaknyelvi kalauz. Budapest, Közgazdasági és Jogi Könyvkiadó. 242-244.

GYARMATHI SÁMUEL 1794. Okoskodva tanító magyar nyelvmester. Kolozsvár-Szeben.

HALÁSz GYUlA [1938]. Engesse és társai. In: HALÁsz GYULA, Édes anyanyelvünk. Budapest, Nyugat Kiadó és Irodalmi R. T. 104-110.

HEGEDÜS ATTILA 2005. A suksükölés nyelvjárási hátteréről és nyelvtudományi megítéléséről. In: Hegedüs ATtila, A változó nyelvjárás. Piliscsaba, Pázmány Péter Katolikus Egyetem BTK. 129-134.

HoRger ANTAL 1931. A magyar igeragozás története. Szeged, Szeged Városi Nyomda és Könyvkiadó Rt.

HORGER ANTAL 1934. A magyar nyelvjárások. Budapest, Kókai Lajos kiadása.

IMRE SAMU 1971. A mai magyar nyelvjárások rendszere. Budapest, Akadémiai Kiadó.

JUHÁSZ JENŐ 1937. Jaj, az a felszólító mód! Magyarosan 6: 141-143.

KÁDÁR EDIT 2014. A suksükölés jelenségköre a magyarban. A kötőmódtól az analógiás túlképzésig - alternatív hipotézis. In: FAZAKAS EMESE-JUHÁSZ DEZSÖ-T. SZABÓ CSILlA-TERBE ERIKA-ZSEMLYEI BORBÁLA szerk., Tér, idö, társadalom és kultúra metszéspontjai a magyar nyelvben. Budapest-Kolozsvár, ELTE Magyar Nyelvtörténeti, Szociolingvisztikai, Dialektológiai Tanszék-Nemzetközi Magyarságtudományi Társaság. 58-75.

KAIBLINGER FÜLÖP 1954. Hozzászólás a „Nyelvmüvelésünk főbb kérdései” című tanulmánygyüjtemény vitájához. Magyar Nyelvőr 78: 150.

KÁlmÁNy LAJOS 1882. Szeged népe 2. Temesköz népköltése. Arad, Réthy Lipót és fia.

KASSAI ILONA 1998. Csoda-e, ha suksükölünk? In: SÁNDOR KLÁRA szerk., Nyelvi változó — nyelvi változás. Szeged, JGyTF Kiadó. 23-25.

KELEMEN BÉLA 1918. Jó magyarság. Tanácsadó a magyar helyesírás, nyelvtan és fogalmazás nehézségeiben. Harmadik, átdolgozott kiadás, Budapest, Athenaeum. 
KEMENES PÁL 1916. Jelentő mód — felszólító mód. Magyar Nyelv 12: 375.

KISS ANDRÁS-PÁL-ANTAL SÁNDOR szerk. 2001: A magyarországi boszorkányság forrásai 3. Budapest, Balassi Kiadó.

KISS JENŐ 1990. A mihályi nyelvjárás változásai 1889 és 1989 között. A Magyar Nyelvtudományi Társaság Kiadványai 190. Budapest.

KONTRA MIKLÓS 1991a. Szukszükölő akadémikus. In: HAJDÚ MIHÁLY-KISS JENŐ szerk., Emlékkönyv Benkö Loránd hetvenedik születésnapjára. Budapest, Akadémiai Kiadó. 372-374.

KONTRA MIKLÓs 1991b. Miért oly lukas Vago magyar fonológiája? Magyar Fonetikai Füzetek 23: 108-110.

KONTRA MiKLÓs 2003a. A vizsgálat keretei. In: KonTRA MiKLÓs szerk. 2003. Nyelv és társadalom a rendszerváltáskori Magyarországon. Budapest, Osiris Kiadó. 41-84.

KONTRA MIKLÓs 2003b. Vizsgálati eredmények: A független változók hatásai a nyelvi változókra. In: KONTRA MIKLÓS szerk. 2003. Nyelv és társadalom a rendszerváltáskori Magyarországon. Budapest, Osiris Kiadó. 85-168.

KONTRA MIKLÓS szerk. 2003. Nyelv és társadalom a rendszerváltáskori Magyarországon. Budapest, Osiris Kiadó.

KONTRA MIKLÓS-VÁRADI TAMÁS 1991. Suksükölő értelmiség. Nyelvhasználatunk néhány kérdése az iskolázottság tükrében. Mozgó Világ 17/2: 61-70.

Kosztolányi Dezső szerk. [1933]. A Pesti Hirlap nyelvőre. Budapest.

KovÁCs PÁL 1833. Thália, eredeti szín-darabok gyüjteménye. Pest.

KOVALOVSZKY MIKLÓs 1953a. Egy új nyelvi járvány. Magyar Nyelvőr 77: 223-227.

KOVALOVSZKY MiKLÓS 1953b. Nyelvünk újabb belső fejleményeinek nyelvhelyességi kérdései. In: LŐRINCZE LAJOS szerk., Nyelvmüvelésünk föbb kérdései. Budapest, Akadémiai Kiadó. 115-197.

KovAlOvsZKY MiKLÓS 1956. Mondhassuk ezt így? In: LŐRINCZE LAJOS szerk., Nyelvmüvelö. Budapest, „Müvelt Nép” Tudományos és Ismeretterjesztő Kiadó. 207-215.

KovAlOvSZKY MiKLÓs 1959. Egy új nyelvi járvány. Mondhassuk ezt így? In: LőRINCZE LAJOS szerk., Iskolai nyelvmüvelö. Budapest, Tankönyvkiadó. 251-261.

KovalovszKy MiKLÓs 1977. Nyelvfejlődés - nyelvhelyesség. Budapest, Akadémiai Kiadó.

KOVALOVSZKY MIKLÓS 1980. felszólító alak kijelentő helyett. In: GRÉTSY LÁSZLÓ-KOVALOVSZKY MikLÓs föszerk., Nyelvmüvelö kézikönyv 1. Budapest, Akadémiai Kiadó. 616-618.

KRIZA JÁNOS 1863. Vadrózsák. Székely népköltési gyüjtemény. Kolozsvár.

KúNOS IGNÁC 1880. A debreczeni nyelvjárás 2. Magyar Nyelvőr 9: 203-207.

LANSTYÁK IsTVÁN 2000. A magyar nyelv Szlovákiában. Budapest-Pozsony, Osiris-Kalligram-MTA Kisebbségkutató Mühely.

MCsNyA. = BODÓ CSANÁD-VARGHA FRUZSINA SÁRA, Jelenségtérképek A moldvai csángó nyelvjárás atlaszából. CD-ROM. Budapest, Eötvös Loránd Tudományegyetem, Magyar Nyelvtörténeti, Szociolingvisztikai, Dialektológiai Tanszék, 2007. 
MELICH JÁNOS 1913. A magyar tárgyas igeragozás. Magyar Nyelv 9: 1-14, 58-67, 105111, 152-161, 207-212, 248-254, 297-306.

MNyA. = DEME LÁSZLÓ-IMRE SAMU szerk., A magyar nyelvjárások atlasza 1-6. Budapest, Akadémiai Kiadó, 1968-1977.

MURÁDIN LÁSZLÓ 1992. A „,suksük nyelv” az erdélyi nyelvjárásokban. Nyelv-és Irodalomtudományi Közlemények 36: 53-62.

N. J. B. 1933 = Nagy J. Béla megjegyzése. Magyarosan 2: 115.

NymKsz. ${ }^{2}$ = GRÉTSY LÁSZLÓ-KEMÉNY GÁBOR szerk., Nyelvmüvelő kéziszótár. A magyar nyelv kézikönyvei 9. Második, javított és bővített kiadás, Budapest, Tinta Kiadó, 2005.

PÁlFi MÁRTON 1902. A nyelvérzék és az iskola. Különlenyomat a Keresztény Magvető 37. évf. 3. füzetéböl. Kolozsvár.

PINTÉR JENÖ 1938. Magyar nyelvvédő könyv. Második, bővített és átdolgozott kiadás. Budapest.

RÁCZ ENDRE-TAKÁCS ETEL 1974. Kis magyar nyelvtan. Negyedik kiadás. Budapest, Gondolat.

RUBINYI MÓZES 1901. Adalékok a moldvai csángók nyelvjárásához. Magyar Nyelvőr 30: 109-116.

RUMY KÁROLY GYÖRGY 1817. Monumenta Hvngarica, az-az: magyar emlékezetes irások 1. Második megjobbított, és Kazinczy Ferencz Úrnak Előbeszédjével megbővített kiadás. Pest.

SÁNDOR ANNA 2000. Anyanyelvhasználat és kétnyelvüség egy kisebbségi magyar beszélöközösségben, Kolonban. Pozsony, Kalligram.

SÁNDOR ANNA 2009. Nyelvjárási jelenségek. In: MENYHÁRT JÓZSEF-PRESINSZKY KÁROLY-SÁNDOR ANNA, Szlovákiai magyar nyelvjárások. Nyitra, Konstantin Filozófus Egyetem, Közép-európai Tanulmányok Kara. 71-107.

SÁNDOR KLÁRA 2014. A székely írás nyomában. Budapest, Typotex.

SCHRAM FERENC 1970. Magyarországi boszorkányperek. 1529-1768. 1. Budapest, Akadémiai Kiadó.

SIMONYI ZSIGMOND 1895. Tüzetes magyar nyelvtan történeti alapon. Balassa József közremüködésével. Budapest.

SimONYI ZsigmOND 1903. Helyes magyarság. Nyelvészeti Füzetek 8. Budapest, Athenaeum.

SIMONYI ZSIGMOND 1919. Szép Ernő: Lila akác. Magyar Nyelvőr 48: 80-82.

SINKOVICS BALÁZS 2010. Felszólító móddal egyező kijelentő módú igealakok a magyar nyelvjárásokban. In: NÉMETH MIKLÓS-SINKOVICS BALÁZS szerk., Tanulmányok Szabó József 70. születésnapjára. Szeged, Szegedi Tudományegyetem Magyar Nyelvészeti Tanszék. 169-177.

SOMSSICH SÁNDOR 1898. Nyelvsajátságok Baranya-Ózd vidékéről. Magyar Nyelvőr 27: 206-210.

Story 2009 = Talmácsi — nyelvtanból elégtelen! In: Story Online 2009. október 14. URL: http://www.storyonline.hu/hirek/talmacsi_suksukol/19508/ (2013. augusztus 6.) 
SZÉKELy MiHÁLy 1818. A' nemes székely nemzetnek constitucióji, Privilegiumai. Pest, Trattner János Tamás.

SZEMERE GYULA 1954. Magyar nyelvtan. Az általános gimnáziumi levelezőoktatás I-IV. osztálya számára. Második kiadás. Budapest, Tankönyvkiadó.

SzEMKÖ ALADÁR 1904. Egy abaúj megyei öző nyelvjárás. Nyelvészeti Füzetek 13: 32-46.

SZENDE ALADÁR 1994. A magyar nyelv tankönyve középiskolásoknak. Budapest, Nemzeti Tankönyvkiadó.

SZENDE ALADÁR 1998. Gyakorlatok és feladatok A magyar nyelv tankönyve középiskolásoknak címü tankönyvhöz. Budapest, Nemzeti Tankönyvkiadó.

SzÉP ERNÖ 1975. Lila ákác. Szerelmes história öt képben, 1921. In: Szép Ernő, Színház. Budapest, Szépirodalmi. 309-416.

SZÉPFALUSI ISTVÁN-VÖRÖS OTTÓ-BEREGSZÁSZI ANIKÓ-KONTRA MIKLÓs 2012. A magyar nyelv Ausztriában és Szlovéniában. Budapest-Alsóö-Lendva, Gondolat.

SzGySz. = FÜREDI MIHÁLY-KELEMEN JÓZSEF szerk., A mai magyar nyelv szépprózai gyakorisági szótára (1965-1977). Budapest, Akadémiai Kiadó, 1989.

SzO. 2. = SZABÓ KÁROLY-SZÁDECZKY LAJOS-BARABÁS SAMU, Székely oklevéltár 2. 1520-1571. Kolozsvár, Magyar Történelmi Társulat, 1876.

SzOkl. = DEMÉNY LAJOS-PATAKI JÓZSEF-TÜDÖS S. KINGA, Székely oklevéltár. Új sorozat. Udvarhely széki törvénykezési jegyzökönyvek 1-3. Bukarest-Budapest, KriterionEurópa, 1983-1994.

SZŐNYI SZILÁRD 2014. Beszélni magyarul? URL: http://jogaszvilag.hu/rovatok/eletmod/ beszelni-magyarul. (2016. október 17.)

SzT. = SZABÓ T. ATTILA-VÁMSZER MÁRTA-KÓSA FERENC-FAZAKAS EMESE szerk., Erdélyi magyar szótörténeti tár 1-14. Bukarest-Budapest-Kolozsvár, Kriterion-Akadémiai Kiadó-Erdélyi Múzeum-Egyesület, 1975-2014.

SzÜTS LÁSZLÓ 1991. Előszó a harmadik kiadáshoz. In: HALÁSZ GYULA, Tudd, hogy mit beszélsz! Budapest, Móra. 5-6.

TAKÁTS LAJOS 1935. Tanítunk-e magyarul? Magyarosan 4: 16-19.

TERBE ERIKA 2013. Adalékok a feltételes mód középmagyar kori használatához. In: FORGÁCS TAMÁS-NÉMETH MIKLÓS-SINKOVICS BALÁZS szerk., A nyelvtörténeti kutatások újabb eredményei 7. Szeged, Szegedi Tudományegyetem BTK, Magyar Nyelvészeti Tanszék. 169-178.

TisZamarti AnTAL 1943. Szeplötlen magyarság. Budapest, Studium.

TolNAi VILMOS 1903. A nyelvérzék és az iskola. Magyar Nyelvőr 32: 97-100.

TOMPA JÓzSEF 1955. Az irodalmi nyelv. In: PAIS DEZSŐ szerk., Nyelvünk a reformkorban. Budapest, Akadémiai Kiadó. 313-434.

ÚGySz. = CSIRIKNÉ CZACHESZ ERZSÉBET-CSIRIK JÁNOS, Újságnyelvi gyakorisági szótár. Szeged-Budapest-Debrecen, Juhász Gyula Tanárképző Főiskola, 1986.

VAJDA LÁSZLÓ 1830. Az erdélyi polgári magános törvények’ historiája. Kolosvár.

VÁRADI TAMÁS-KONTRA MIKLÓS 1994. A stigmatizált magyar kijelentő mód társadalmi disztribúciójáról. In: KEMÉNY GÁBOR-KARDOS TAMÁs szerk., A magyar nyelvi 
norma érvényesülése napjaink nyelvhasználatában. Budapest, MTA Nyelvtudományi Intézet. 115-124.

VARGHA FRUZSINA SÁRA 2007. Nyelvi változók A magyar nyelvjárások atlasza hangfelvételeiben. In: GuTTMANn MIKLÓS-MolnÁR ZolTÁN szerk., V. Dialektológiai Szimpozion. A Berzsenyi Dániel Főiskola Magyar Nyelvészeti Tanszékének Kiadványai 8. Szombathely. 279-289.

VelCSOV MÁRTONNÉ 1968. Alaktan. In: BENCÉDy JóZSEF-FÁBIÁN PÁL-RÁCZ ENDRE VELCSOV MÁRTONNÉ, A mai magyar nyelv. Budapest, Tankönyvkiadó. 85-204.

VERESS JENÖ 2015. Suksük államtitkár. Népszava 2015. december 10. URL: http://nepszava.hu/cikk/1079223_suksuk-allamtitkar (2016. október 17.)

ViOLA LuJZA 2012. A suksükölésről. In: VajdaságMA. Délvidéki hírportál. 2012. január 16. URL: http://www.vajma.info/cikk/anyanyelvunk/10/A suksukoles.html (2013. augusztus 6.)

VÖÖNÉ PÉCS MÁRIA 1933. Felszólító mód a jelentő mód helyett. Magyarosan 2: 114115.

ZOLNAI GYULA 1889. Egri nyelvsajátságok. Magyar Nyelvőr 18: 16-25.

ZOLNAI GYULA 1891. Mátyusföld nyelvjárása. Magyar Nyelvőr 20: 73-86.

\section{The Stigmatized Indicative Forms of $\boldsymbol{t}$-final Verbs}

In standard Hungarian $t$-final verbs maintain a difference between indicative and imperative forms: lássa 'see-3Sg.-Imp.Def.' and látja 'see-3Sg.-Ind.Def.'; halassza 'postpone-3Sg.Imp.Def.' and halasztja 'postpone-3Sg.Ind.Def.'. In nonstandard Hungarian both are realized in the form of standard Hungarian imperative, and many regard it as a serious grammatical mistake. I discuss its origin, its spread in dialects and in "low" registers of urban language.

There are data for the nonstandard variant since the $18^{\text {th }}$ century but it was used in the popular registers for centuries. It emerged in the language of the urban lower classes in the late $19^{\text {th }}$ century, and it was strictly corrected at that time by teachers. In the literature of language cultivation it was considered as a stylistic regionalism for decades but it became highly stigmatized in the 1930's.

Keywords: history of Hungarian $t$-final verbs, stigmatised nonstandard variant 